Nina Ilic ${ }^{*}$

Faculty of Philosophy

University of Novi Sad
UDC 811.163.41'232'367.625-053.4

DOI: $10.19090 /$ gff.2020.5.75-94

Originalni naučni rad

\title{
ARE PROTOTYPICAL SEMANTIC CONCEPTS ACQUIRED FIRST?***
}

The aim of the present research was to examine the production of three types of $s e$-verbs at different stages of first language acquisition of Serbian. The verbs tested were true reflexive (e.g. oblačiti se 'dress oneself'), true reciprocal (e.g. grliti se 'hug each other'), and anticausative verbs (e.g. otvoriti se 'open'). None of the tested types is syntactically simple, because they do not involve a canonical linking of semantic roles and syntactic functions (agent-subject and patient-object). However, it was expected that true reflexive verbs would be acquired before true reciprocal and anti-causative verbs, because they are less complex. They are the only type that mirrors prototypical semantic concepts, although the agent and patient theta-roles are both mapped onto the subject. A total of sixty subjects belonging to three age groups (31-42, 43-55, 56-68 months-twenty participants in each group) took part in the research. The data collection technique was a verb elicitation task. The children were asked to name the activities presented in the pictures. The number of tested verbs was the same for each verb type. The initial hypothesis was confirmed, since the production of true reflexive verbs was the most accurate across groups.

Key words: first language acquisition, verb production, reflexive verbs, reciprocal verbs, anti-causative verbs, semantic concepts, semantic-syntactic mapping

\section{INTRODUCTION}

The question of how children learn verbs has been one of the crucial questions in the study of language acquisition. It has been claimed that children follow a canonical order that links thematic roles to syntactic functions (agentsubject and patient-object) (Pinker, 1984). However, canonical linking is not

\footnotetext{
*nina.ilic.ns@gmail.com

** The paper is part of the research on Project No. 178002, entitled Languages and Cultures in Time and Space, which is funded by the Serbian Ministry of Education, Science and Technological Development. The paper was presented at ELALT 5 conference on March 9, 2019, at the Faculty of Philosophy, University of Novi Sad.
} 
present with all the verbs (e.g. anti-causative verbs, where the patient performs the function of the subject). It is exactly the question of how children acquire these verbs that researchers attempt to answer. According to Pinker, "how argument structures are acquired is intertwined with the question of why particular verbs are paired with particular argument structures" (Pinker, 1989: 5). That is why the study on the acquisition of Serbian $s e$-verbs is suitable not only for gaining an insight into the way children acquire argument structures, but also for a better understanding of the nature of these verbs.

The aim of the present study is to test and compare the production of true reflexive, true reciprocal ${ }^{1}$ and anti-causative verbs at different stages of language acquisition in Serbian. It is expected that true reflexive verbs are acquired before true reciprocal and anti-causative verbs and will therefore be produced more accurately, because they are syntactically and semantically less complex. True reflexive verbs are the only type of $s e$-verbs that reflects prototypical semantic concepts (although the agent and patient theta-roles are mapped only onto the subject), whereas reciprocal verbs involve two arguments that are both agents and patients at the same time, and anti-causative verbs involve a complex process of derivation from a transitive verb (including the elimination of the external +cause theta-role).

The paper is organized as follows. Section 2 will deal with the theoretical background. First, reflexive, reciprocal and anti-causative verbs in Serbian will be looked into, paying attention to how they have been defined in traditional Serbian grammars, as well as within the generative approach. Then, each category of severbs will be illustrated and explained in terms of their syntactic and semantic complexity and prototypicality. An outline of the hypothesis about the innateness of semantic roles will be provided next, followed by an overview of studies on the acquisition of reflexive and anti-causative verbs. After the theoretical background, in section 3, a detailed description of the method will be given. Section 4 will deal with the analysis and discussion of the results obtained. Finally, in section 5, we will summarize the limitations and the main contributions of the research.

\footnotetext{
${ }^{1}$ Inherent/lexical reflexive and reciprocal verbs are beyond the scope of this paper. For more information, see Miličević (2015).
} 


\section{THEORETICAL BACKGROUND}

\subsection{Se-verbs in Serbian}

\subsubsection{Reflexive verbs in Serbian grammars}

A reflexive verb is an umbrella term for all the verbs that appear with the clitic se in Serbian. However, Serbian linguists have pointed out that the reason for using it should be looked for in the Serbian linguistic tradition, rather than the nature of these verbs (Ivić, 1961-62; Stevanović, 1954; Arsenijević, 2011). The only unifying element of these verbs is the clitic se, even though the consensus on its own lexical-syntactic status has not been reached yet.

The most widely accepted classification of Serbian reflexive verbs is the one into true reflexive, quasi reflexive and reciprocal reflexive verbs (StanojčićPopović, 2002). True reflexive verbs denote activities which the agent of the verb performs on himself/herself. In this case, the clitic se is interpreted as the accusative case of the reflexive pronoun sebe 'self' (oblaciti se 'dress oneself'). On the other hand, quasi reflexive verbs denote activities or states in which the clitic se cannot be interpreted as the accusative case of the reflexive pronoun sebe 'self' (e.g. igrati se 'play'). Reciprocal reflexive verbs mark activities in which the agents perform activities on each other (ljubiti se 'kiss each other'). Other types of se-verbs (middles, impersonal, anti-causative verbs etc.) are not included in this classification.

As Samardžić (2006) points out, such a classification is not based on a unique criterion. While the interpretation of the clitic se is taken as an indicator of true reflexive verbs, its function is not defined with quasi reflexive verbs, and it is only stated how it cannot be interpreted. With reciprocal verbs, the clitic se is not mentioned at all.

In the following section, we are going to look at a different approach to the verbs that appear with the clitic se, namely the generative approach.

\subsubsection{Generative approach to se-verbs}

Reinhart-Siloni (2003) offer a different approach to se-verbs, focusing on their derivation. As Reinhart-Siloni (2003) claim, arity operations, which change the valency of the verb, apply in syntax in Serbo-Croatian. The authors (2003) show how the clitic se appears in constructions in which the syntactic valency of the verb is reduced. The clitic se is a morphological component of the verb which reduces 
the case. When it appears, the internal theta-role of the verb cannot be assigned to its canonical position and thus it remains unassigned until the external argument is merged. When the external argument is merged, bundling takes place, i.e. two thetaroles are assigned to the same argument. That is how Reinhart-Siloni (2003) explain the possibility of the subject bearing two theta roles at the same time (those of the agent and patient), which happens with reflexive verbs. According to Siloni (2008), the reciprocalization operation also prevents the assignment of the internal $\theta$-role due to the lack of case. The internal $\theta$-role is not eliminated, but gets associated with the external $\theta$-role, and forms a reciprocal meaning.

Moreover, whereas traditional classifications of $s e$-verbs in Serbian do not provide any account of anti-causative verbs, which also appear with the clitic se, this type is also included in their theory. Reinhart-Siloni define decausativization (turning a transitive into an anti-causative verb) as the "reduction of an external [ $+\mathrm{c}]$ role" (Reinhart-Siloni, 2005: 416). The external argument is removed before the remaining argument is merged internally. At the final step of the derivation, after the internal argument is merged, it moves to a higher position, to become the subject.

It has been claimed that reciprocal verbs possess more agentive properties than reflexive verbs. According to Rákosi (2008), reciprocal verbs are more active than reflexive verbs. For example, while reflexive verbs in Hungarian show features of both unaccusativity and unergativity, because they take patient as their second argument, reciprocals behave more like unergatives, since their second argument takes the role of a "secondary Agent". This point is also taken by Siloni (2008), who uses a number of tests in Hebrew, French, Italian and Russian to show that reciprocal verbs are unergative. According to Siloni, "reciprocalization is a universal operation that associates two roles with one - external - argument..." (Siloni, 2008: 461).

Semantic and syntactic complexity of the tested se-verbs and their relation to prototypical transitivity will be outlined in the next section.

\subsubsection{Prototypicality of se-verbs}

The notion of prototypical transitivity, as defined by Hopper \& Thomson (1980), involves a volitional animate agent affecting the state of an inanimate patient. These thematic roles are linked to the syntactic functions of subject and object. True reflexive verbs are the only type of $s e$-verbs that mirror prototypical transitivity relation, since there is a volitional animate agent who affects the state of a patient. However, the patient is animate and coreferential with the subject in this 
case. Both theta-roles are mapped onto the subject. The clitic se can be replaced with the reflexive pronoun sebe 'self' as shown in (1):

1) a. Dečak se oblači.

boy.nom SE get dressed.3sg.pres

'The boy is dressing himself.'

b. Dečak oblači sebe.

boy.nom dress.3sg.pres himself.acc

'The boy is dressing himself.'

When it comes to true reciprocal verbs, the situation becomes more semantically complex, since there are two agents who affect the state of an animate patient and are the patients themselves at the same time. Both theta-roles are associated with the external argument. The clitic se can be replaced with the complement jedan drugog 'each other', as exemplified in (2).

2) a. Dečak i devojčica se ljube.

boy.nom and girl.nom SE kiss.3pl.pres

'The boy and the girl are kissing.'

b. Dečak i devojčica ljube jedan drugog.

boy.nom and girl.nom kiss.3pl.pres one another

'The boy and the girl are kissing each other.'

Finally, in terms of prototypical transitivity, anti-causative verbs are the least prototypical and the most syntactically and semantically complex type of the tested $s e$-verbs, since the patient theta-role, which is prototypically mapped onto the syntactic function of object (3a), moves to the position of the external argument to become the subject of the sentence, after the agent theta-role is eliminated ( $3 \mathrm{~b})$.

3) a. Marko je otvorio vrata. (agent-subject, patient-object)

marko.nom open.3sg.past door.acc

'Marko opened the door'

b. Vrata su se otvorila. (agent is eliminated; patient is mapped onto the subject)

door.nom SE open.3sg.past

'The door opened.' 
Because of the multitude of syntactic conditions in which they appear, severbs form a suitable research area for testing the hypothesis about the innateness of semantic roles (Pinker, 1984, 1989), which will be the topic of the next section.

\subsection{Innateness of semantic roles}

The development of grammar involves finding out the right syntactic functions for the thematic roles of Agent, Theme, Goal etc. (Pinker, 1984, 1989). Pinker says that his theory is "about how the child begins learning syntax" (Pinker, 1994: 385). He assumes the existence of universal linking rules, which are innate and help children draw conclusions. For instance, one linking rule is that agents are subjects of active sentences. Once a child recognizes a certain word as the agent in a given context, he/she can infer that that word is also in the position of the subject.

As Pinker states, "certain contingencies between perceptual categories and syntactic categories, mediated by semantic categories, could help the child get syntax acquisition started" (Pinker, 1994: 385). Pinker (1989) introduced the idea of children's learning classes of verbs via broad and narrow semantic constraints. Broad constraints are directly associated with universal linking rules for mapping conceptual structures to syntax. They define the semantic roles of the arguments of a verb in general. Narrow constraints refer to very subtle nuances in meaning, which children need more time to master. According to Pinker (1989), when a child makes an overgeneralization, that happens because the child is not yet able to assign the verb to the narrow class to which it belongs (see Brooks-Tomasello, 1999).

Interestingly, Brooks-Tomasello (1999) obtained results which support Pinker's hypothesis about narrow semantic constraints (Pinker, 1989). In an experiment which included ninety-six children, Brooks-Tomasello (1999) tested Pinker's hypothesis that children base their use of verbs on their belonging to narrow-range semantic classes. They also tested the hypothesis that children make use of indirect negative evidence, i.e. that the forms which they hear in the cases where they would expect to hear a different pattern prevent them from using those verbs in more expected constructions. The conclusions of the experiment are very interesting, since both hypotheses were confirmed. The prediction that the children would respect the assigned transitivity of a verb more often if the verb belonged to a fixed transitivity class (either transitive or intransitive) than if it belonged to alternating transitivity verbs proved to be true. It was shown that it takes some time for children (from 2.5 to 4.5 years) to recognize which verbs occur with which argument structures. Therefore, the results provide empirical support for Pinker's hypothesis (1989) about narrow semantic constraints. Brooks-Tomasello (1999) 
also found that providing children with an alternative construction - different from what they might expect based on the given situation but still keeping the verb's transitivity - tended to preempt their usage of that verb.

\subsection{Previous research on the acquisition of reflexive and anti-causative verbs}

Data from cross-linguistic research show that reflexive verbs are acquired pretty early in the course of language acquisition. Snyder-Hyams and Crisma's (1995) findings show that reflexive verbs do not pose a difficulty for children, since one French-speaking child (in her transcripts ranging between the ages 2;1;9 and 3;3;12 ) and three Italian-speaking children (all younger than three) selected the right auxiliary with reflexive verbs almost without any mistakes.

However, the situation with some other types of se-verbs is not that clear. According to the studies that support the Maturational hypothesis (Borer-Wexler, 1987), children are expected to have difficulty acquiring anti-causative verbs, because of their inability to form A-chains, i.e. to perform movement to an argument position. Moreover, the results of various studies looking into the children's use of anti-causative verbs show that children are likely to come up with implicit agents, which are not present in the structure of anti-causative verbs (Roeper, 1987; Bowerman, 1991; Verrips, 2000).

When it comes to the results obtained for the acquisition of Serbian severbs, the results from a pilot study on the production of true reflexive, true reciprocal and anti-causative verbs suggest that children have more difficulty producing anti-causative $s e$-verbs than reflexive or reciprocal verbs (Ilić, 2019), which is in accordance with the prototypicality scale described in the section 2.1.3. However, the results of this study need to be taken with caution due to a limited number of participants. There were only twenty-seven participants that were tested in the study.

A study that looked into the acquisition of $s e$-verbs in Croatian as L2 (Pavlinušić-Kelić, 2001) came to a similar conclusion. True reflexive, quasi reflexive and reciprocal verbs were tested prior to, immediately after and some time after the language instruction on $s e$-verbs was provided. True reflexive verbs were produced most accurately in all three testing situations. Pavlinušić-Kelić (2001) concluded that linguistic structures which mark prototypical semantic concepts are acquired first. 


\section{CORPUS AND METHOD}

\subsection{Participants}

A total of sixty monolingual Serbian-speaking children belonging to three age groups (twenty participants each) took part in the research. The age range in group 1 was $31-42$ months $(\mathrm{N}=20, \mathrm{M}=37.75, \mathrm{SD}=2.88)$. The age of three was chosen as the starting point because that is usually the earliest age for testing children (Eisenbeiss, 2010). Moreover, we tried to conduct the experiment with 2year-old children, but it was impossible, because of their lack of attention on the task. The age range in group 2 was 43-55 months $(\mathrm{N}=20, \mathrm{M}=50.65, \mathrm{SD}=2.99)$; and it was 56-68 months in group $3(\mathrm{~N}=20, \mathrm{M}=61.55, \mathrm{SD}=4.19)$. None of the children selected had any language impairment, learning disability or hearing loss. Kindergarten teachers provided all the children's relevant information (the child's birth date and information about their mother tongue). Children were tested in February 2019, in "Maslačak" kindergarten, "Radosno detinjstvo" preschool facility in Novi Sad. Parental consent forms were obtained prior to the testing for every child. Parents also gave their permission for the sessions to be audio-taped using a Dictaphone/voice recorder.

\subsection{Instrument and Procedure}

The data collection technique was a structured interview with a verb elicitation task. The participants were tested in single sessions that lasted up to 10 minutes. The interviewer's descriptions and questions were prepared in advance in order to prevent using the words that were being elicited from the children. The children were asked to name the activities presented in the pictures. Each stimulus contained two pictures. The examiner would tell the child what was presented in the first picture and elicit the answer for the second picture (Figure 1). All the stimuli are given in Appendix $1 .{ }^{2}$ The child was expected to look at the picture and the interviewer would ask him/her what the person in the picture was doing in case of animate arguments of the verb (testing the production of true reflexive and reciprocal verbs) or what happened in case of inanimate ones (testing the production of anti-causative verbs). An example of one situation is the following:

\footnotetext{
${ }^{2}$ The author would like to thank Viktorija Stanković, a second-year student at the Academy of Arts in Novi Sad, for drawing the stimuli.
} 
Interviewer: Oni ovde sede, a šta rade ovde?

'They are sitting here, and what are they doing here?'

Interviewee: Ljube se.

'They are kissing.'

Figure 1-Stimulus for ljubiti se 'kiss each other'

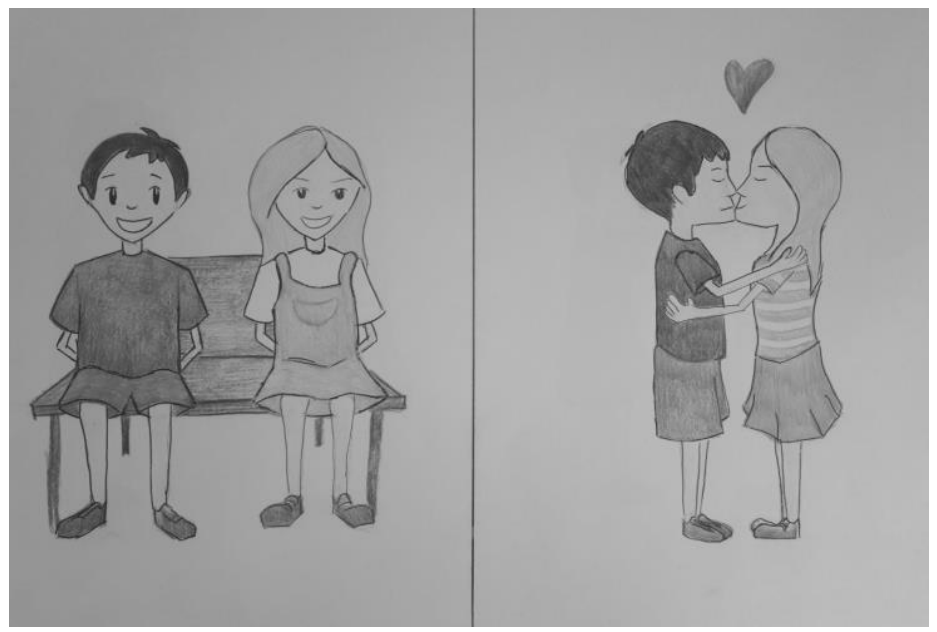

The number of tested verbs was the same for each verb type (six), which makes a total of 18 target verbs presented to every participant:

1. true reflexive: oblačiti se 'dress oneself', umivati se 'wash one's face', brisati se 'wipe oneself', kupati se 'wash oneself', češljati se 'comb one's hair', šminkati se 'put on make-up';

2. true reciprocal: grliti se 'hug each other', ljubiti se 'kiss each other', udarati seltuci se 'hit each other', juriti se/vijati se 'chase each other', gađati se 'throw something at each other', gledati se 'look at each other';

3. anti-causative verbs: otvoriti se 'open', zatvoriti se 'close', upaliti se 'turn on', ugasiti se 'go out', pokvariti se 'break', polomiti se 'break'.

\footnotetext{
${ }^{3}$ As an anonymous reviewer notes, the verb gledati se could also be classified as a true reflexive verb under the reading of "looking at themselves in the mirror". Although such an interpretation might have been known to the children as suggested by the reviewer, it was not available in the stimulus. Moreover, the results of producing individual reciprocal verbs have shown that this verb was quite difficult to produce in comparison with others.
} 
The data were analyzed with the Mixed Effects Logistic Regression (GLMER), in the R free statistical software (R Core Team, 2017), by using lme4 (Bates et al., 2019) and lmerTest (Kuznetsova-Brockhoff-Bojesen, \& Jensen, 2019) packages. Three analyses were conducted (for true reflexive, true reciprocal and anti-causative verbs). The dependent variable was verb production coded as target or non-target (no answer or non-target word), and the independent variable was age. Verb length and frequency effects were also examined, as co-variables. Verb frequencies were taken from Serbian Web Corpus $(\mathrm{SrWaC})$ (Ljubešić-Klubička, 2016). Verb length was quantified by counting the number of letters.

\section{RESULTS}

\subsection{GLMER analyses}

The results of the first GLMER analysis (true reflexive verbs) presented in Table 1 suggest that there is a significant difference in the production of true reflexive verbs at the age of three and the age of four $(\beta=1.056 ; z=2.672$; $\operatorname{Pr}(>|z|)=.007 * *)$, as well as at the age of three and the age of five $(\beta=1.182$; $\mathrm{z}=2.914 ; \operatorname{Pr}(>|\mathrm{z}|)=.003 * *)$. True reflexive verbs were produced more successfully at the ages of five and four than at the age of three. No significant difference was found between the ages of four and five $(\beta=.125 ; \mathrm{z}=.272 ; \operatorname{Pr}(>|z|)=.785)$.

Table 1-Reflexive verb production across groups

\begin{tabular}{lcccc}
\hline Random effects & & & Variance & $S D$ \\
\hline Subject : Intercept & & & .220 & .469 \\
Stimuli : Intercept & Estimate & $S E$ & .162 & .402 \\
\hline Fixed effects & 1.317 & .418 & 3.150 & p-value \\
\hline Intercept & .011 & .018 & .594 & .552 \\
Trial Order & -.289 & .267 & -1.084 & .278 \\
Verb Frequency & -.708 & .347 & -2.036 & $.041^{*}$ \\
Verb Length & 1.056 & .395 & 2.672 & $.007^{* *}$ \\
Age (4-year-olds) & 1.182 & .405 & 2.914 & $.003^{* *}$ \\
Age (5-year-olds) & & & & \\
\hline
\end{tabular}

The second GLMER model (true reciprocal verbs) suggests that there is a significant difference in the production of true reciprocal verbs between all the tested ages (shown in Table 2), which was not the case with true reflexive verbs. Reciprocal verbs were produced more accurately at the age of four than at the age of three $\left(\beta=1.676 ; z=4.349 ; \operatorname{Pr}(>|z|)=.000^{* * *}\right)$. Moreover, they were produced more 
successfully at the age of five than at the age of three $(\beta=2.777 ; z=6.456$; $\operatorname{Pr}(>|z|)=.000 * * *)$, or at the age of four $(\beta=1.101 ; z=2.958 ; \operatorname{Pr}(>|z|)=.003)$.

Table 2-Reciprocal verb production across group

\begin{tabular}{lcccc}
\hline Random effects & & & Variance & SD \\
\hline Subject : Intercept & & & .156 & .396 \\
Stimuli : Intercept & & & 1.272 & 1.128 \\
\hline Fixed effects & Estimate & SE & z-value & p-value \\
\hline Intercept & -.576 & .603 & -.955 & .339 \\
Trial Order & .036 & .042 & .845 & .397 \\
Verb Frequency & 1.539 & .632 & 2.434 & $.014^{*}$ \\
Verb Length & -1.872 & .642 & -2.912 & $.003^{* *}$ \\
Age (4-year-olds) & 1.676 & .385 & 4.349 & $.000^{* * *}$ \\
Age (5-year-olds) & 2.777 & .430 & 6.456 & $.000^{* * *}$ \\
\hline
\end{tabular}

The last GLMER analysis (anti-causative verbs) presented in Table 3 supports the results of the previous GLMER analysis. Anti-causative verbs were produced more accurately at the age of four than at the age of three $(\beta=1.156$; $\left.\mathrm{z}=3.909 ; \operatorname{Pr}(>|\mathrm{z}|)=.000^{* * *}\right)$, as well as at the age of five than at the age of three $\left(\beta=1.814 ; \mathrm{z}=5.676 ; \operatorname{Pr}(>|\mathrm{z}|)=.000^{* * *}\right)$. Moreover, five-year-olds produced anticausative verbs significantly better than four-year-olds $(\beta=0.657 ; \quad z=2.106$; $\operatorname{Pr}(>|z|)=.035)$.

Table 3-Anti-causative verb production across groups

\begin{tabular}{lcccc}
\hline Random effects & & & Variance & SD \\
\hline Subject : Intercept & & & .240 & .490 \\
Stimuli : Intercept & & & .655 & .809 \\
\hline Fixed effects & Estimate & SE & z-value & p-value \\
\hline Intercept & -.655 & .466 & -1.405 & .160 \\
Trial Order & .016 & .014 & 1.072 & .284 \\
Verb Frequency & .102 & .377 & .272 & .786 \\
Verb Length & .746 & .322 & 2.317 & $.020^{*}$ \\
Age (4-year-olds) & 1.156 & .295 & 3.909 & $.000^{* * *}$ \\
Age (5-year-olds) & 1.814 & .319 & 5.676 & $.000^{* * *}$ \\
\hline
\end{tabular}

The results indicate that children have more difficulty producing reciprocal and anti-causative verbs than producing reflexive verbs. The effect of verb length was significant for all verbs types, whereas the frequency effect was only significant for reciprocal verbs. This implies that more frequent reciprocal verbs are acquired before less frequent ones, whereas the same could not be stated for other verb types, at least according to the present results. 
In figure 2, we can see that the participants had no difficulty producing true reflexive verbs (94/120) from the earliest age. Unlike the production of reflexive verbs, the production of true reciprocal verbs (54/120) and anti-causative verbs (50/120) did not reach even 50\% in the youngest tested group. Figure 2 also shows that the production of both reciprocal and anti-causative verbs increased steadily (81/120 reciprocal verbs produced in Group 2 and 98/120 in Group 3; 78/120 anticausative verbs produced in Group 2 and 92/120 in Group 3). On the other hand, the production of true reflexive verbs was above $90 \%$ in both Group 2 and Group 3. Non-target answers will be briefly discussed in the next section.

Figure 2 - Overall verb production across groups

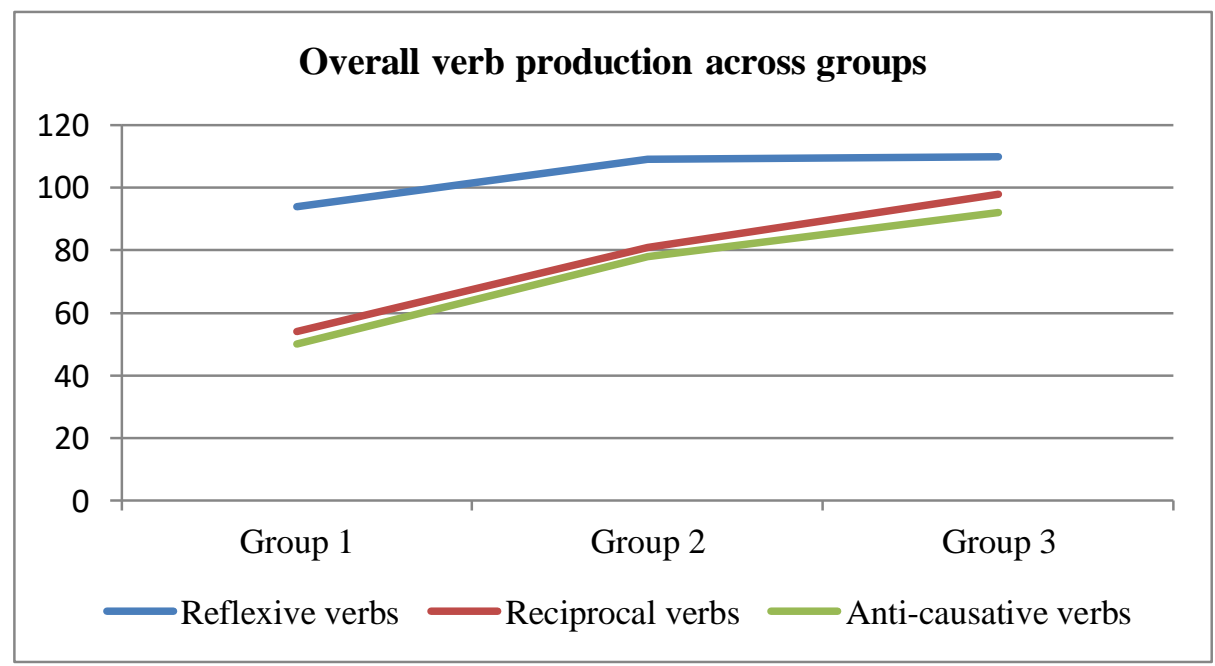

\subsection{Non-target answers}

For reasons of space, non-target answers cannot be discussed in detail. However, an overview of the most common non-target answers for each verb type will be provided.

The number of non-target answers was the lowest for true reflexive verbs (26/120 in Group 1, 11/120 in Group 2, and 10/120 in Group 3). Alternative answers in all the groups most often included verbs with complements instead of their variants with the clitic se (e.g. kosu četka 'she is brushing her hair' instead of češlja se 'she is brushing herself'). Answers of this kind point to these children's tendency to use prototypical semantic-syntactic mapping (agent-subject and patientobject). 
As far as non-target answers for true reciprocal verbs are concerned, their number was much higher than the number of non-target answers for true reflexive verbs (66/120 in Group 1, 39/120 in Group 2, and 22/120 in Group 3). Non-target answers most often included non-target verbs. The children would choose unergative or transitive verbs, with co-agents instead of simultaneous agents and patients (e.g. bacaju 'they are throwing' instead of gađaju se 'they are throwing pillows at each other'). As it can be seen from the example given, the verbs that they used instead of the target ones were more prototypical in terms of transitivity, or they were syntactically less complex, as was the case with unergative verbs.

Finally, anti-causative verb type yielded most non-target answers (70/120 in Group 1, 42/120 in Group 2, and 28/120 in Group 3). Alternative answers in all the groups most often included non-target verbs. In almost half of the cases, the children used verbs that involved the presence of an agent, which is not present in the structure of anti-causative verbs, which again points to their preference towards prototypical semantic concepts. For example, instead of the target answer ugasila se 'it went out', one participant said duvaju deca 'the children are blowing', which is more prototypical in terms of transitivity and semantic-syntactic mapping.

\section{DISCUSSION AND CONCLUSION}

The aim of the present research study was to test the production of true reflexive, true reciprocal and anti-causative verbs at different stages of language acquisition, in order to gain some insight into the way children acquire se-verbs of different syntactic and semantic complexity. Based on the data obtained in different age groups, it can be concluded that true reflexive verbs are acquired before reciprocal and anti-causative verbs. Therefore, the initial hypothesis was confirmed. The results suggest that $s e$-verbs that mirror prototypical semantic concepts are acquired before those that do not, which replicates the results of previous studies (Pavlinušić-Kelić, 2001; Ilić, 2019). Moreover, non-target answers have shown the children's tendency towards prototypical linguistic structures. As was noted in previous research (Roeper, 1987; Bowerman, 1991; Verrips, 2000), the children tend to insert agents with anti-causative verbs.

Regarding the limitations of the research, the frequencies of the target verbs in child language could not be explored in detail, because there are only eight available transcripts of Serbian-speaking children in the CHILDES database (Anđelković, Ševa \& Moskovljević, 2001), which is a small number if one is to look into specific verb types. For that reason, the frequency of the verbs was taken from Serbian Web Corpus (SrWaC). When it comes to the limitations of the stimuli, 
experiments with children are sensitive to inference based on 'knowledge of the world' (Verrips, 2000). It might be the case that with some non-target answers children chose to focus on what would happen in the real world, regardless of the exact representation in the stimulus. Finally, the age of the participants may be taken as another limitation of the study, which prevents any definite conclusions regarding the innateness of thematic roles being drawn.

Finally, our intention is to repeat the experiment longitudinally after a year, in order to obtain a more complete understanding of the development of true reflexive, true reciprocal and anti-causative se-verbs in Serbian and track the further development of reciprocal and anti-causative verbs.

Nina Ilić

\section{DA LI SE PROTOTIPIČNI SEMANTIČKI KONCEPTI USVAJAJU PRVI?}

Rezime

Najšire prihvaćena podela povratnih glagola jeste trodelna podela na prave povratne, neprave povratne i uzajamno-povratne glagole (Stanojčić-Popović, 2002). Međutim, kako navodi Samardžić (2006), ovakva podela glagola nema jedinstven kriterijum. Dok se tumačenje klitike se pominje kao kriterijum za definisanje pravih povratnih glagola, kod nepravih se njeno značenje ne pominje, već se samo navodi kako se ona ne može tumačiti kao akuzativ povratne zamenice sebe. Kod uzajamno-povratnih glagola se njena uloga uopšte ne pominje. Analizirajući različite konstrukcije glagola sa klitikom se, RajnhartSiloni (2003) pokazuju da se reč se javlja kada jedan od argumenata nestane iz sintakstičke reprezentacije. Autorke govore i o derivaciji anti-kauzativnih glagola, kod kojih se spoljašnji argument briše, a unutrašnji obavlja funkciju subjekta (Rajnhart-Siloni, 2005). Cilj ovog istraživanja jeste da se uporedi produkcija pravih povratnih, uzajamno-povratnih i antikauzativnih glagola kod dece uzrasta približno 3, 4 i 5 godina (po 20 ispitanika u svakoj grupi). Prethodna istraživanja su pokazala da deca nemaju poteškoća sa usvajanjem povratnih glagola na ranom uzrastu (Snyder, Hyams \& Crisma, 1995), dok se očekuje da usvajanje anti-kauzativnih glagola bude otežano (Borer-Wexler, 1987; Brooks-Tomasello, 1999; Roeper, 1987; Bowerman, 1991; Verrips, 2000). Inicijalna hipoteza je bila da se pravi povratni glagoli usvajaju prvi, jer su samo kod njih pristutne dve prototipične tematske uloge (agensa i pacijensa), koje se preslikavaju na funkciju subjekta na nivou sintakse. S druge strane, kod recipročnih glagola su prisutna dva argumenta, koja istovremeno obavljaju i funkciju subjekta i funkciju objekta, dok anti-kauzativne glagole karakteriše sintaksički kompleksan proces derivacije iz tranzitivnog glagola. Istraživanje je sprovedeno pomoću struktuiranih intervjua uz korišćenje unapred pripremljenih vizuelnih stimulusa (crteži), a od dece se tražilo da produkuju glagol prikazan na slikama. Rezultati istraživanja ukazuju na to da deca ne usvajaju sve vrste glagola sa klitikom se istom brzinom. Pravi povratni glagoli se 
produkuju sa većom tačnošću od uzajamno-povratnih i anti-kauzativnih glagola na različitim stupnjevima razvoja govora. Ovi podaci svedoče o različitom stepenu sintaksičke i semantičke kompleksnosti povratnih glagola i idu u prilog tezi da se prototipične semantičke strukture usvajaju prve.

Ključne reči: usvajanje maternjeg jezika, produkcija glagola, povratni glagoli, uzajamno povratni glagoli, anti-kauzativni glagoli, semantičko-sintaksičko mapiranje

\section{REFERENCES}

Anđelković, D.-Ševa, N. \& Moskovljević, J. (2001). Srpski elektronski korpus ranog dečijeg govora. Beograd, Srbija: Laboratorija za eskperimentalnu psihologiju, Filozofski fakultet u Beogradu; Katedra za opštu lingvistiku, Filološki fakultet u Beogradu.

Arsenijević, N. (2011). Prilog proučavanju povratnih glagola u srpskom jeziku. Zbornik Matice srpske za filologiju i lingvistiku, LIV(1), 115-135.

Bates, D.-Mächler, M.-Bolker, B.-Walker, S.-Bojesen, R.-Singmann, H. \& Fox, J. (2019). lme4: Linear Mixed-Effects Models using 'Eigen' and S4. R package version 1.1-21.

Borer, H.-Wexler, K. (1987). The maturation of syntax. In: Roeper, T.-Williams, E. (eds.) (1987). Parameter Setting. Dordrecht: Reidel. 23-172.

Bowerman, M. (1991). When a patient is the subject: sorting out passives, anticausatives, and middles in the acquisition of English. Paper presented at the symposium on Voice, University of California, Santa Barbara, CA.

Brooks, P.-Tomasello, M. (1999). How children constrain their argument structure constructions. Language, 75, 720-738.

Eisenbeiss, S. (2010). Using production methods in language acquisition research. In: Blom, E.-Unsworth, S. (eds.) (2010). Experimental methods in language acquistion research. Amsterdam/Philadelphia: Benjamins. 11-34.

Hopper, P. J.-Thompson, S. A. (1980). Transitivity in grammar and discourse. Language, 56, 251-299.

Ilić, N. (2019). Is there an effect of syntactic complexity on the acquisition of severbs in Serbian? In: Damnjanović, K.-Tošković, O. \& Marković, S. (eds.) (2019). Proceedings of the XXV scientific conference Empirical Studies in Psychology. Beograd: Filozofski fakultet. 22-24.

Ivić, M. (1961/62). Jedan problem slovenske sintagmatike osvetljen transformacionim metodom (gramatička uloga morfeme se $u$ srpskohrvatskom jeziku). Južnoslovenski filolog, 25, 137-148. 
Kuznetsova, A.-Brockhoff, P.-Bojesen, R. \& Jensen, S. (2019). lmerTest: Tests in Linear Mixed Effects Models. R package version 3.1-1.

Ljubešić, N. -Klubička, F. (2016). The Serbian web corpus srWaC. Ljubljana: Jožef Stefan Institute.

Miličević, M. (2015). Između neakuzativnosti i neergativnosti: Povratno, uzajamnopovratno i autokauzativno se. In: Arsenijević, B.-Halupka-Rešetar, S. (eds.) (2015). Srpski jezik u savremenoj lingvističkoj teoriji. Niš: Filozofski fakultet. 175-192.

Pavlinušić, E.-Kelić, M. (2011). Utjecaj poucavanja na ovladanost povratnim glagolima u hrvatskome kao inome jeziku. LAHOR, 11, 5-22.

Pinker, S. (1984). Language learnability and language development. Cambridge, MA: Harvard University Press.

Pinker, S. (1989). Learnability and Cognition: The Acquisition of Argument Structure. Cambridge, MA: MIT Press.

Pinker, S. (1994). How Could a Child Use Verb Syntax to Learn Verb Semantics? Lingua, 92, 377-410.

$\mathrm{R}$ Core Team (2017). $R:$ A language and environment for statistical computing. Vienna: R Foundation for Statistical Computing.

Rákosi, Gy. (2008). The inherently reflexive and the inherently reciprocal predicate in Hungarian: Each to their own argument structure. In: König, E.-Gast, V. (eds.) (2008). Reciprocals and Reflexives: Theoretical and Typological Explorations. Berlin and New York: Mouton de Gruyter. 411-450.

Reinhart, T.-Siloni, T. (2003). Thematic Arity Operations and Parametric Variations. OTS working papers in linguistics, TL-03-001, University of Utrecht.

Reinhart, T.-Siloni, T. (2005). The lexicon-syntax parameter: reflexivization and other arity operations, Linguistic Inquiry, 36 (3), 389-436.

Roeper, T. (1987). Implicit arguments and the head-complement relation. Linguistic Inquiry, 18, 267-310.

Samardžić, T. (2006). Reč se u argumentskoj strukturi ditranzitivnih glagola. Naučni sastanak slavista u Vukove dane, 35(1), 179-193.

Siloni, T. (2008). The syntax of reciprocal verbs: An overview. In: König, E.-Gast, V. (eds.) (2008). Reciprocals and Reflexives: Theoretical and Typological Explorations. Berlin and New York: Mouton de Gruyter. 451-498.

Snyder, W.-Hyams, N. \& Crisma, P. (1995). Romance Auxiliary Selection with Reflexive Clitics: Evidence of early knowledge of Unaccusativity. In: 
Clark, E. (eds.) (1995). Proceedings of Child Language Research Forum 26. Stanford, CA: CSLI.

Stanojčič, Ž.-Popović, Lj. (2002). Gramatika srpskog jezika. Beograd: Zavod za udžbenike i nastavna sredstva.

Stevanović, M. (1954). Povratni glagoli. Književnost i jezik u školi, 5, 303-316.

Verrips, M. (2000). Passives and implicit arguments in child language. In: Howell, S. C.-Fish, S.A. \& Keith-Lucas, T. (eds.) (2000). Proceedings of the 24th Annual Boston University Conference on Language Development. Somerville, MA: Cascadilla Press. 749-760. 


\section{APPENDIX 1: VISUAL STIMULI - DRAWINGS}

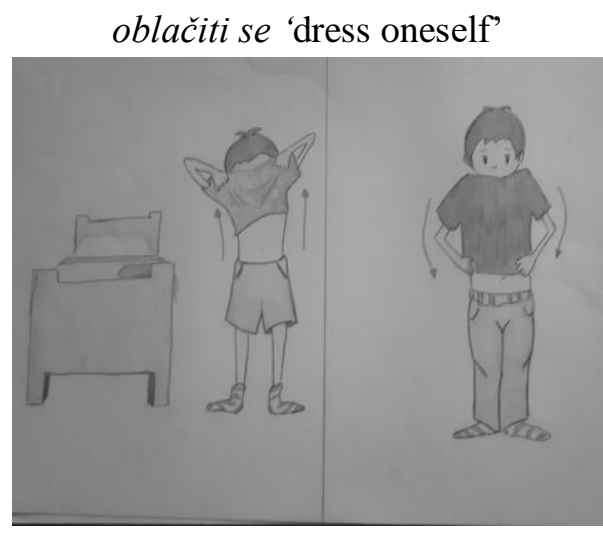

brisati se 'wipe oneself'

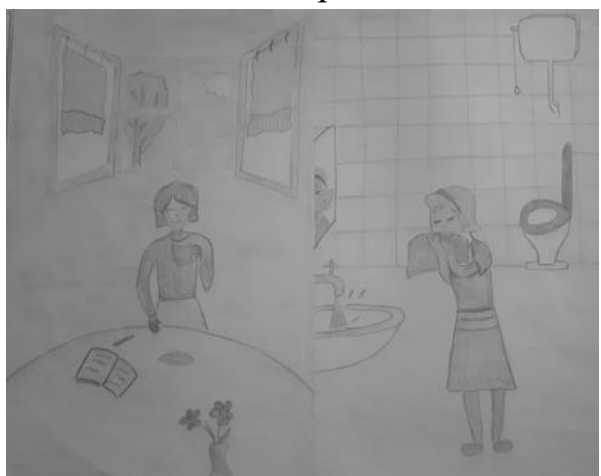

češljati se 'comb one’s hair'

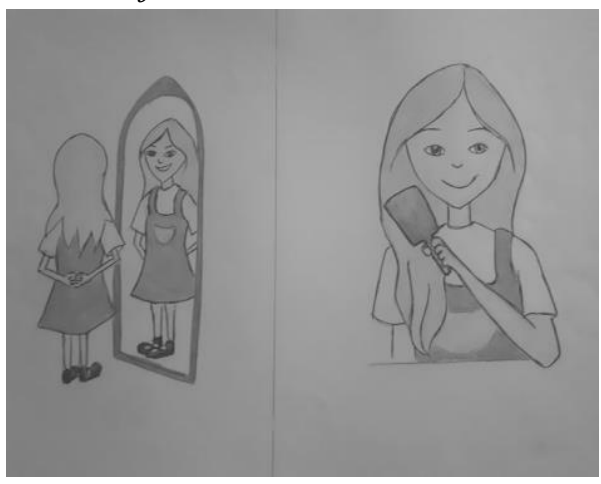

umivati se 'wash one's face'

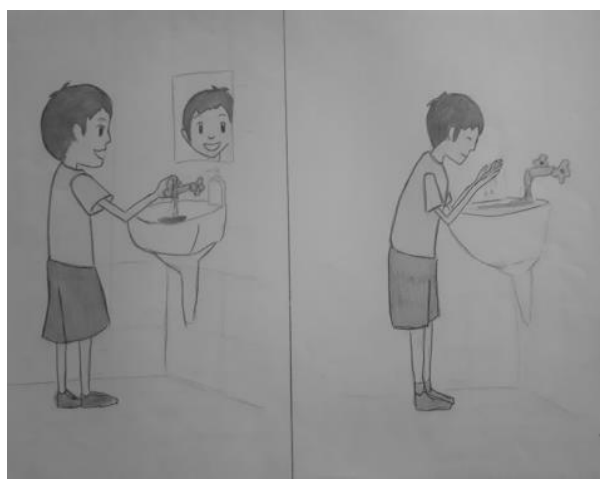

kupati se 'wash oneself'

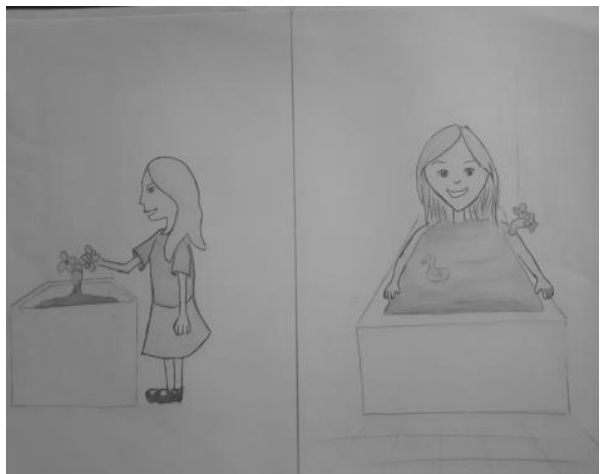

šminkati se 'put on make-up'

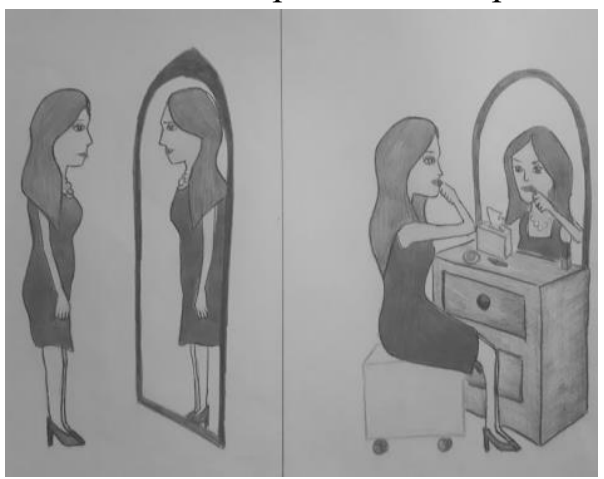


grliti se 'hug each other'

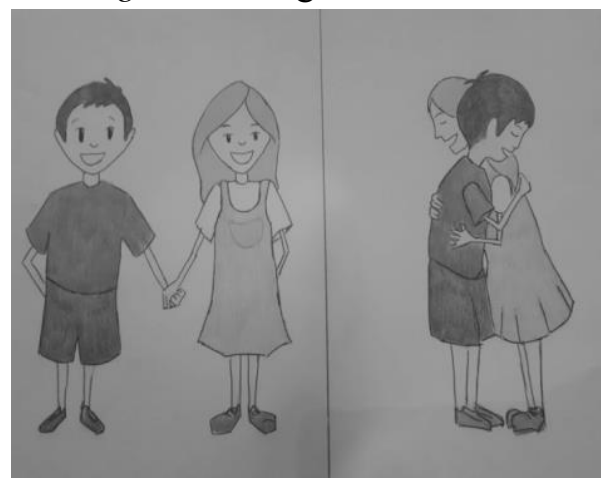

udarati seltući se 'hit each other'

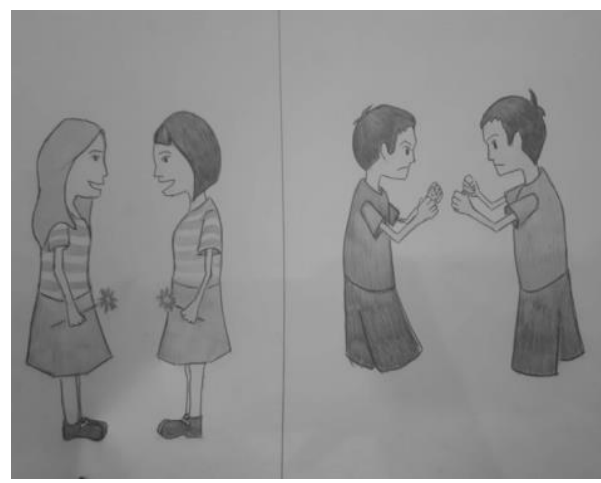

gađati se 'throw something at each other'

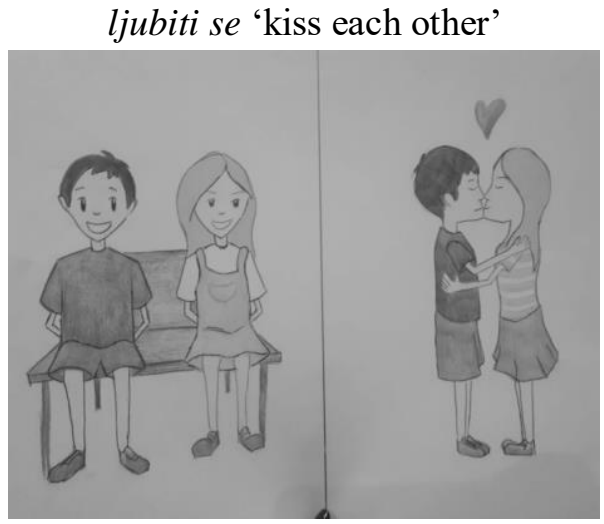

juriti se/vijati se 'chase each other'

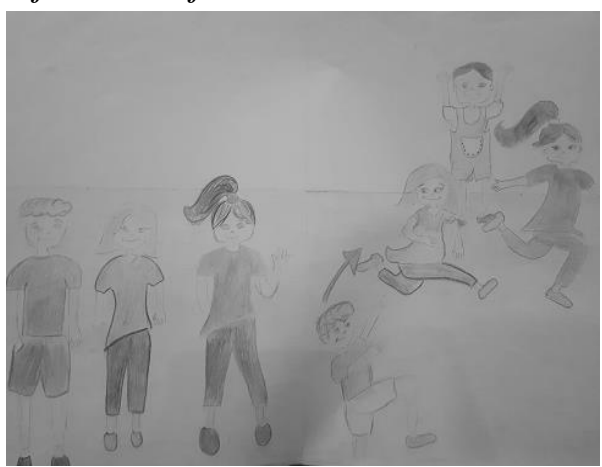

gledati se 'look at each other'
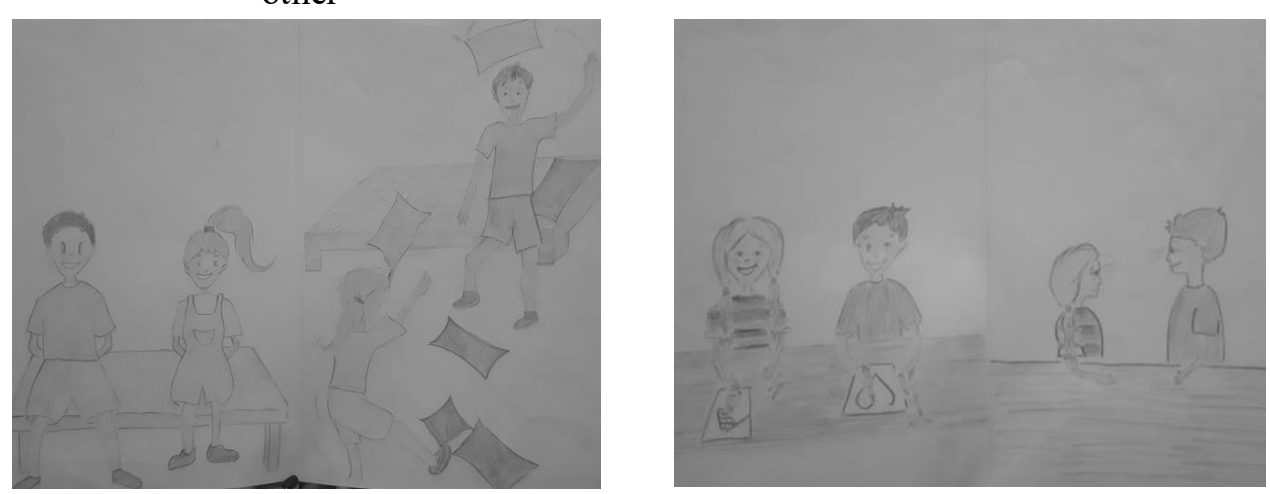


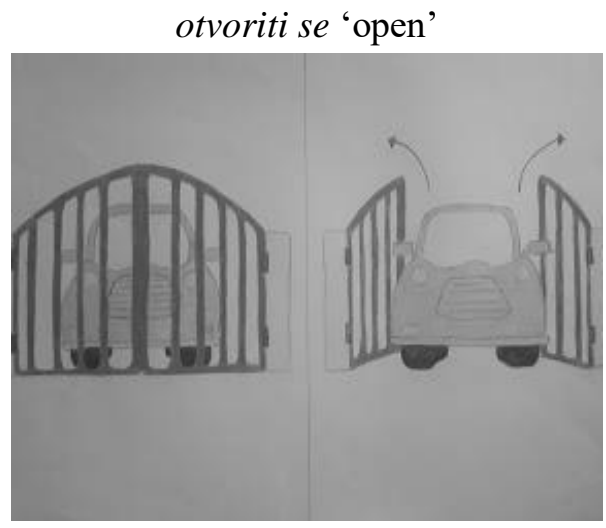

upaliti se 'turn on'

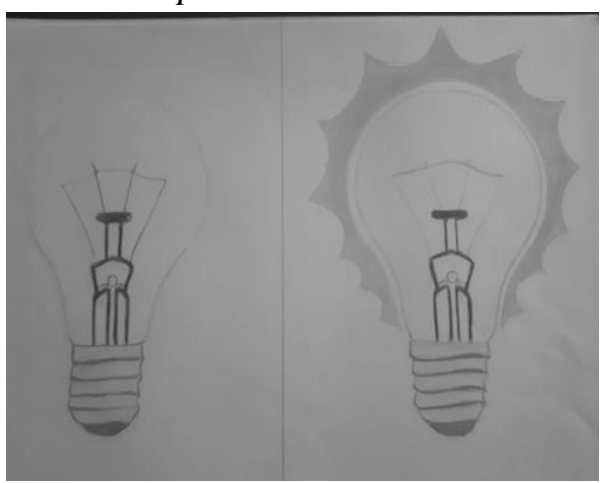

pokvariti se 'break'

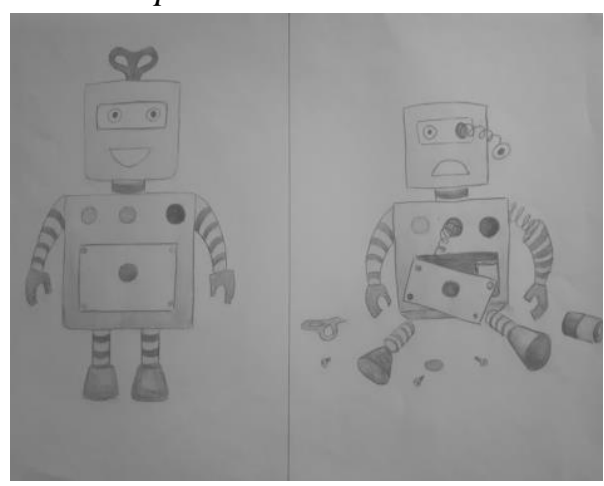

zatvoriti se 'close'

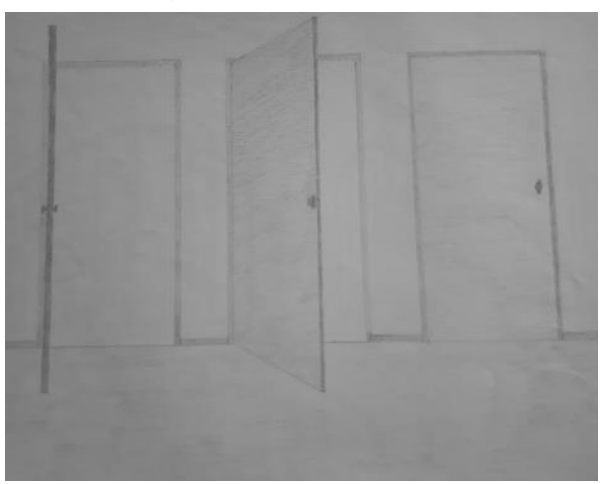

ugasiti se 'go out'

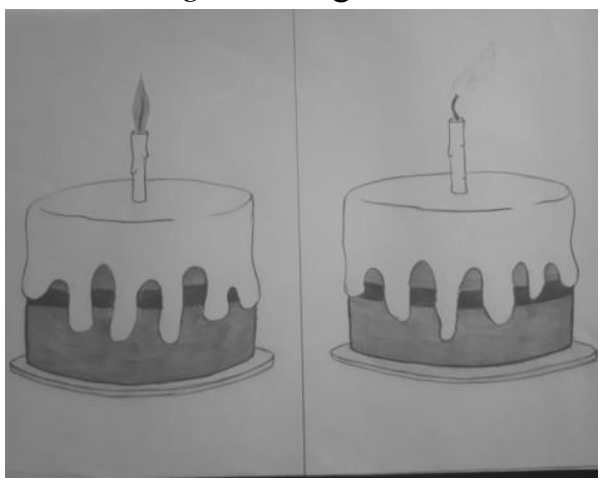

polomiti se 'break

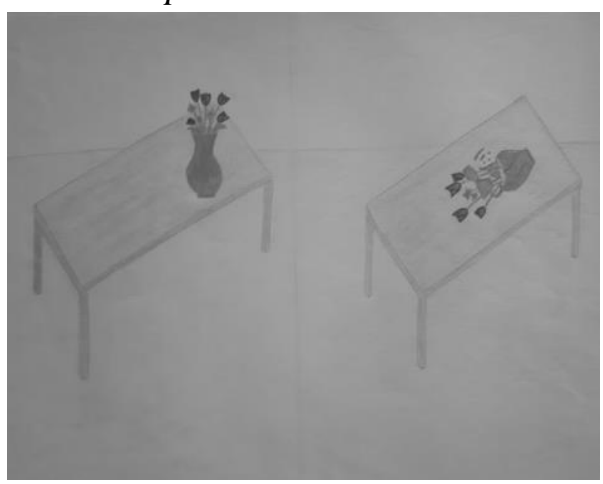

